Jacques Forestier des Stades aux Thermes-vie d'un grand rhumatologue 1890-1978. By Jacques Arlet. Pp. 134. 120F. National Public Productions: Aix-lesBains, France. 1988. ISBN 2-7089-8908-1.

May I commend to your readers this recent biography of Jacques Forestier, the doyen of French rheumatology and of international renown. This labour of love by one of the most distinguished of his pupils-Professor Jacques Arlet of Toulouse-details not only the four generations of his medical ancestry, his sporting achievements (international rugby), his distinguished war record, his scientific achievements such as the introduction of lipiodol for imaging the airways, his enthusiastic introduction of gold for arthritis, his description (with Certoncin) in 1953 of polymyalgia, and his depiction of hyperostosis (with Jaqueline and Rotes-Querol), later called Forestier's disease, but also his major role as a caring physician in Aix-les-Bains, where his son François continues to practise.

This book is well illustrated with family and medical photographs, including those of his first visit to America in $1925-6$, and later ones. Nor is the foundation of the International League against Rheumatism, in which he played an important part, neglected.

He died after a meeting in Paris in his honour and to which he notably contributed.

This affectionate and detailed study of Forestier's role in the development of modern rheumatology makes fascinating reading and is accompanied by a select bibliography and a list of the (roughly) 180 subscribers.

\section{Emeritus Professor of}

E G L BYWATERS

\section{Notes}

\section{Xth PanAmerican Congress of Rheumatology}

The congress will be held on 11-16 March 1990 in Guadalajara, Jalisco, Mexico, under the auspices of the PanAmerican League Against Rheumatism and organised $\vec{\circ}$ by the Sociedad Mexicana de Reumatologia. Further $\vec{\overrightarrow{ }}$ information from Secretariat, Xth PanAmerican Congress $\vec{\omega}$ of Rheumatology, PO Box 71-275, Mexico City 06900.

\section{Second European ANA symposium}

This will be held from 25 to 27 May 1989 in Leuven, Belgium. Further information from Dr $\mathbf{M}$ Walravens, Universitaire Ziekenhuizen, Leuven, Belgium.

Rheumatology,

University of London,

Royal Postgraduate Medical

School of London

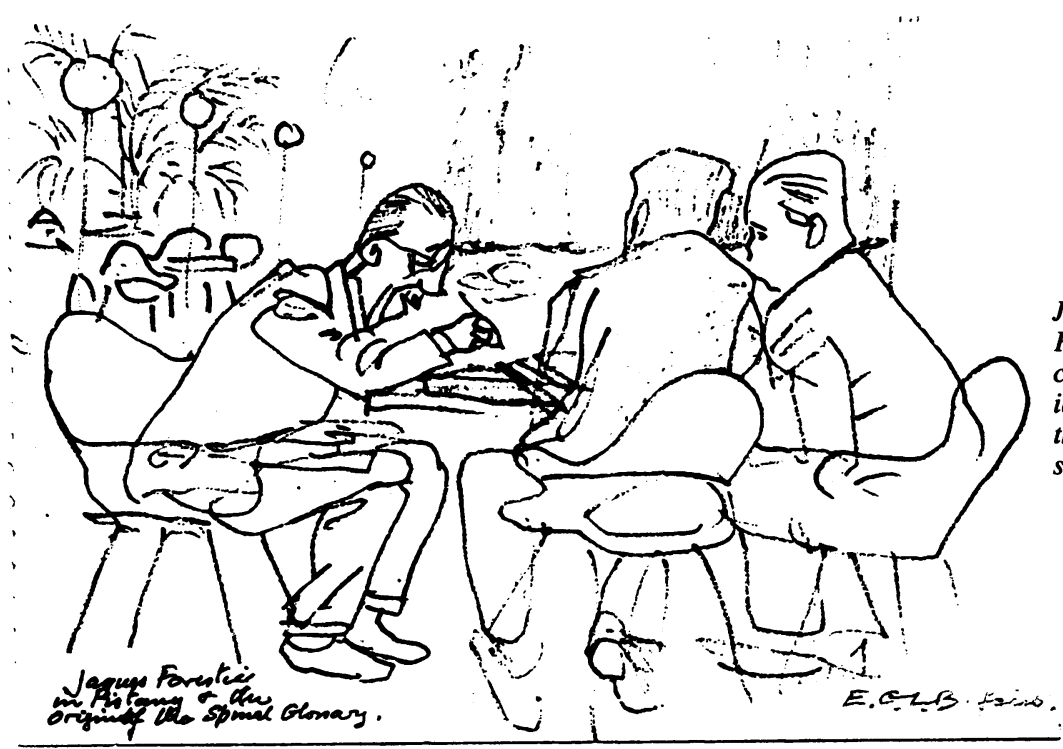

Jacques Forestier on the terrace, Piestany-at the international congress in 1969 -expounding his ideas on the difference between $\mathrm{N}$ the osteophyte and the syndesmophyte to two neophytes. N 